\title{
\begin{tabular}{c|l} 
Volume: & E-ISSH: 2656-940X 굴 \\
Nomor: \\
Bulan:
\end{tabular} \\ Tahun: URL: jurnal.ideaspublishing.co.id
}

\section{Meningkatkan Keterampilan Berpikir Siswa pada Materi Ikatan Kimia melalui Pendekatan STEM PBL Science}

\author{
Hamzah Utina \\ SMA Negeri 4 Gorontalo \\ Pos-el: hamzah_utina@yahoo.com \\ DOI: $10.32884 /$ ideas.v\%vi\%i.272
}

\begin{abstract}
Abstrak
Penelitian ini bertujuan untuk meningkatkan hasil belajar siswa dalam pembelajaran kimia melalui STEM. Pendekatan STEM merupakan suatu pendekatan modern untuk menyelesaikan masalah pada abad ke-21 yang menuntut siswa mampu berinovasi khususnya dalam pembelajaran. Jenis penelitian ini adalah penelitian tindakan kelas (PTK). Populasi dalam penelitian ini adalah siswa kelas X IPA 3 SMA Negeri 4 Gorontalo. Model penelitian ini berbentuk siklus yang terdiri dari empat tahapan, yaitu: perencanaan, tindakan, observasi, dan refleksi. Hasil penelitian menunjukkan, bahwa pendekatan STEM dapat meningkatkan hasil belajar siswa dalam pembelajaran kimia, serta melatih kemampuan inovasi siswa dalam mengaitkan empat bidang ilmu eksakta sehingga memiliki wawasan yang luas dan mendalam. Kata Kunci: hasil belajar, pembelajaran, STEM
\end{abstract}

\section{Pendahuluan}

Mata pelajaran kimia menjadi sangat penting kedudukannya dalam masyarakat karena kimia selalu berada di sekitar kita dalam kehidupan sehari-hari. Kimia adalah satu mata pelajaran yang mempelajari mengenai materi dan perubahan yang terjadi di dalamnya. Namun, selama ini masih banyak siswa yang mengalami kesulitan dalam memahami dan mengikuti pelajaran kimia. Hal ini tidak terlepas dari materi yang dipelajari dalam kimia lebih bersifat abstrak.

Upaya meningkatkan mutu siswa dalam menguasai konsep-konsep sains untuk memecahkan masalah dalam kehidupaan sehari-hari dilakukan melalui berbagai inovasi dan program pendidikan. Upaya-upaya tersebut antara lain penyempurnaan kurikulum, pengadaan buku ajar, buku referensi, bahkan pengadaan multimedia di sekolah. Peningkatan mutu pendidik dan tenaga kependidikan dilakukan melalui berbagai pelatihan, penataran, dan peningkatan kualifikasi pendidikan. Pengamatan terhadap beberapa indikator menunjukkan bahwa upaya tersebut belum menunjukkan adanya peningkatan mutu yang dilakukan secara signifikan.

Penguasaan ilmu eksakta berupa science, technology, engineering, dan mathematics dapat dilakukan melalui pendekatan model pembelajaran STEM yaitu intregasi antar empat 


\section{TE E-ISSH: 2656-940X Volume: \\ P-ISSH: 2442-367K Nomor: \\ URL: jurnal.ideaspublishing.co.id Tahun:}

disiplin ilmu yaitu ilmu pengetahuan, teknologi, teknik, dan matematika dalam pendekatan interdisipliner yang diterapkan berdasarkan konteks dunia nyata. Hal ini pun dapat mendorong peserta didik mengembangkan keterampilan dan kompetensi untuk pendidikan, karir, dan kehidupan. Model pembelajaran dengan menggunakan pendekatan STEM diharapkan mampu membentuk peserta didik untuk dapat berpikir logis, memecahkan masalah dari berbagai situasi, serta menguasai teknologi dan dapat mengaitkan budaya yang dimiliki dalam pembelajaran abad ke-21 ini.

Abad ke-21 merupakan abad dengan perkembangan teknologi yang pesat di berbagai negara. Siswa dituntut dapat menguasai berbagai keterampilan agar dapat bersaing secara global. Perkembangan ilmu pengetahuan dan teknologi menuntut peningkatan mutu pendidikan. Pendidikan berperan untuk menyiapkan sumber daya manusia yang mampu berpikir secara mandiri, kreatif dan kritis. Hal ini karena pendidikan merupakan modal dasar bagi pembangunan manusia berkualitas.

Kenyataannya, keterampilan berpikir kreatif Indonesia masih tergolong rendah. Terlihat dari hasil The Global Creativity Index tahun 2015, Indonesia berada pada peringkat ke-115 dari 139 negara (Florida, Mellander, \& King, 2015). Oleh karena itu dalam pembelajaran di sekolah sangat perlu dikembangkan suatu pembelajaran yang mendukung peningkatan kemampuan berpikir kreatif siswa dan pemahaman konsep siswa. Hendaknya semua guru dapat mengembangkan keterampilan kreatif siswa dan pemahaman konsep mereka sehingga siswa mampu bergerak ke arah aktualisasi diri dan mampu menghadapi era globalisasi.

Kondisi seperti ini terjadi pada siswa kelas X IPA SMA Negeri 4 Gorontalo ketika diajari konsep ikatan kimia. Siswa cenderung pasif dan berdampak pada rendahnya keterampilan berpikir kreatif siswa dan rendahnya hasil nilai siswa akibat kurangnya pemahaman konsep kimia. Hal ini terlihat dari nilai rata-rata kognitif atau ulangan harian siswa kelas X pada materi sebelumnya yaitu 65,4, sedangkan KKM yang ditentukan sebesar 75. Keterampilan berpikir kreatif siswa yang masih rendah ini juga terlihat pada keseharian mereka ketika guru memberikan suatu permasalahan, siswa sulit untuk memecahkannya dan cenderung pasif hanya mengandalkan jawaban dari buku panduan. Permasalahan bagi guru adalah cara mengemas proses pembelajaran agar menarik minat siswa untuk meningkatkan keterampilan berpikir kreatif siswa dan meningkatkan pemahaman konsep siswa. 


\section{\begin{tabular}{c|l} 
Volume: & E--ISSH: 2656-940X \\
$\begin{array}{r}\text { Nomor: } \\
\text { Bulan: } \\
\text { Tahun: }\end{array}$ & P-ISSH: 2442-367K \\
URL:jurnal.ideaspublishing.co.id
\end{tabular}}

Berdasarkan penelitian Mayasari, T. Kadarohman, A. Rusdiana dan Kaniawati, I. (2016) didapatkan hasil dengan membuat produk kreatif dengan mengintegrasikan pengetahuan STEM sehingga mampu mempengaruhi 3 tingkat kreativitas siswa. Kreatif dipengaruhi oleh pengetahuan STEM yang dapat mendukung kreativitas siswa dengan mengintegrasikan pengetahuan, keterampilan, dan kemampuan memecahkan masalah sehari-hari.

Untuk mengatasi rendahnya berpikir kreatif siswa, Kuhltau, Maniotes \& Caspari dalam Afandi, A. (2013) memberikan pendapat bahwa pendekatan STEM PBL Science membantu siswa dapat berpikir secara kreatif. Selain itu, pembelajaran menggunakan pendekatan STEM PBL Science juga diperkuat dengan penelitian sebelumnya, yaitu Sa'adhah dan Evawati (2019), Ana Amelia (2018/2019) serta Murniati yang menunjukkan bahwa penerapan strategi pendekatan STEM sangat efektif dalam meningkatkan hasil belajar siswa.

\section{Metode}

Penelitian tindakan ini dilaksanakan di kelas X-IPA 3 SMA Negeri 4 Gorontalo yang terdaftar pada semester ganjil tahun pelajaran 2019/2020. Jumlah siswa yang dikenai tindakan sebanyak 30 orang yang terdiri dari 5 orang laki-laki dan 25 orang perempuan.

\section{Langkah-Langkah Penelitian}

\section{Tahap Persiapan}

1. Memberitahukan kepada kepala sekolah.

2. Menetapkan persiapan dan memberitahukan kepada guru mitra yang membantu pelaksanaan tindakan.

3. Membuat persiapan mengajar/perangkat pembelajaran meliputi silabus, rencana pembelajaran dan buku-buku penunjang.

4. Menetapkan waktu pelaksanaan tindakan.

5. Mencatat alat evaluasi yang terdiri dari lembar observasi dan tes hasil belajar tentang konsep ikatan kimia. Sebelum melaksanakan pembelajaran dengan menggunakan pendekatan STEM, maka guru harus melaksanakan kegiatan awal pada pelaksanaan tindakan di kelas.

Kegiatan dalam tahap ini adalah sebagai berikut.

1. Membentuk kelompok model pembelajaran menggunakan pendekatan STEM

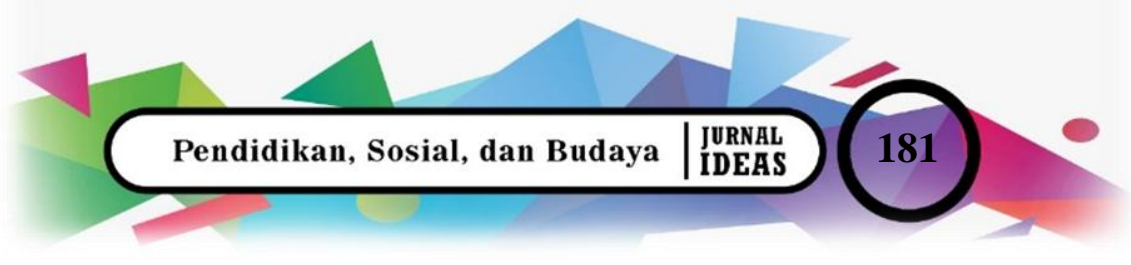




\section{TE E-ISSH: 2656-940X Volume: \\ D.ISSH: 2442-367K Nomor: \\ URL: jurnal.ideaspublishing.co.id Tahun:}

Kelompok pembelajaran STEM terbagi menjadi 6 orang siswa yang bervariasi. Terdiri dari laki-laki dan perempuan, berasal dari berbagai suku dengan kemampuan pengetahuan yang beragam.

2. Pembagian materi

Mengingat konsep pembelajaran pendekatan STEM, maka materi diberikan kepada siswa dalam bentuk bahan merancang/membuat bentuk molekul.

3. Merencanakan agar siswa memiliki pemahaman yang jelas tentang peran mereka dan harapan-harapan guru pada saat mereka berperan serta dalam suatu pelajaran dengan pendekatan STEM.

\section{Tahap Pelaksanaan}

Pelaksanaan tindakan terdiri atas dua tahap dengan langkah-langkah sebagai berikut.

Tahap I

1. Pelaksanaan kegiatan pembelajaran terdiri dari:

a. Menyampaikan tujuan pembelajaran.

b. Menjelaskan materi ikatan kimia secara rinci

c. Menyampaikan pertanyaan

d. Memberikan waktu kepada siswa untuk berfikir

e. Menjawab pertanyaan

2. Memantau pelaksanaan tindakan

3. Mengadakan evaluasi dengan tes tertulis

4. Melaksanakan analisis evaluasi hasil belajar

5. Mengadakan refleksi terhadap hasil pemantauan dan tes

Tahap II

1. Memperbaiki dan merumuskan penyempurnaan pelaksanaan tindakan

2. Melaksanakan penyempurnaan tindakan

3. Memantau pelaksanaan tindakan

4. Mengevaluasi pelaksanaan tindakan

5. Melaksanakan refleksi lanjutan 


\section{Volume: \\ Nomor: \\ Bulan: \\ Tahun:

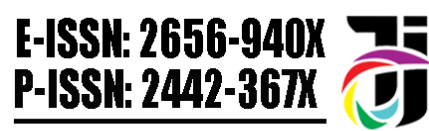 \\ URL:jurnal.ideaspublishing.co.id}

\section{Tahap Akhir}

Merangkum hasil pelaksanaan tindakan, faktor-faktor penunjang serta penghambat dalam pelaksanaan tindakan di antaranya:

1. mengumpulkan data penelitian

2. menyusun konsep laporan penelitian

3. mendiskusikan dengan guru mitra

4. konsultasi dengan kepala sekolah tentang konsep laporan yang diajukan untuk memperoleh persetujuan

5. menyusun program akhir penelitian

6. mengadakan laporan hasil penelitian tindakan kelas.

\section{Rancangan Tindakan}

Rancangan tindakan yang dilaksanakan pada penelitian ini adalah sebagai berikut.

1. Mengidentifikasi permasalahan

2. Menetapkan pokok bahasan dan indikator yang dicapai dalam pembelajaran

3. Menetapkan model pembelajaran yang tepat sesuai dengan pokok bahasan dan tingkat pengetahuan siswa

4. Menyusun skenario konsep pembelajaran pendekatan STEM PBL Science yang telah ditetapkan.

5. Menyiapkan materi / bahan bacaan

6. Mengatur tindakan yang akan dilakukan

a. Menganalisis kemampuan siswa dalam materi reaksi oksidasi-reduksi

b. Mempersiapkan perangkat pembelajaran seperti silabus dan sistem penilaian, RPP, lembar pengamatan guru dan siswa

c. Mengadakan kegiatan pembelajaran pendekatan STEM.

d. Mengadakan hasil belajar

7. Menyiapkan soal-soal tes dan latihan yang dikerjakan oleh individu, sebagai penguatan terhadap materi yang telah diajarkan.

8. Mendiskusikan dengan guru mitra.

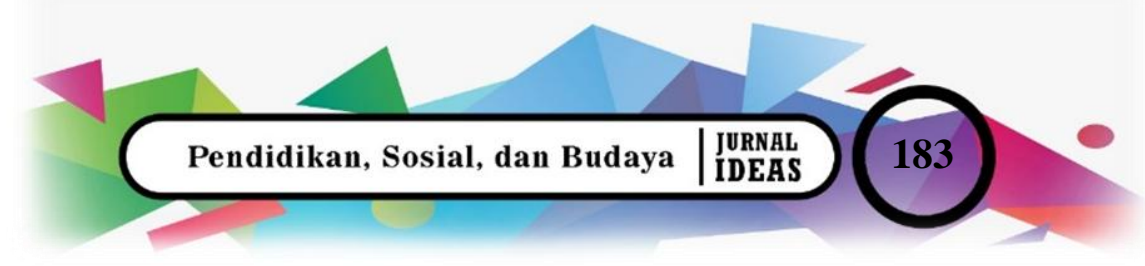




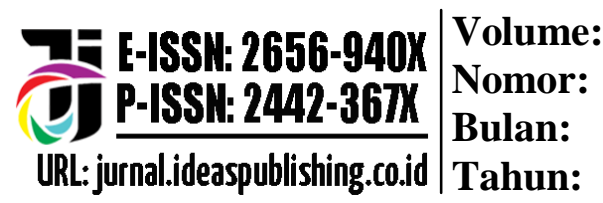

\section{Observasi}

Observasi dilakukan untuk merekam aktivitas belajar siswa. Selain itu, juga untuk memperoleh data tentang kelemahan dari strategi pembelajaran yang diterapkan untuk diadakan perbaikan pada siklus berikutnya.

\section{Refleksi}

Pada tahap ini dianalisis hasil observasi dan tes hasil belajar siswa untuk menemukan kekurangan dan kelebihan dari konsep pembelajaran yang diterapkan, serta merumuskan tindakan perbaikan.

\section{Alat Pengumpul Data}

Instrumen yang digunakan untuk mengumpul data dalam penelitian ini meliputi:

1. lembar observasi

2. lembar keberhasilan kegiatan pembelajaran berupa tes tertulis

\section{Kriteria Penilaian}

Kriteria pencapaian tujuan tindakan penelitian ini yaitu:

1. Jika hasil pengamatan terhadap proses pembelajaran yang meliputi kegiatan guru dan siswa telah mencapai $75 \%$ atau lebih dari seluruh aspek kegiatan yang diamati mencapai target, maka kegiatan pembelajaran dinyatakan berhasil.

2. Jika $85 \%$ siswa yang dikenai tindakan memperoleh nilai 75,0 ke atas dengan daya serap rata-rata $75 \%$, maka tindakan dinyatakan berhasil.

\section{Analisis Data}

Analisis data dimaksudkan untuk mengetahui ketuntasan belajar siswa. Data yang diperoleh dari kegiatan pembelajaran dianalisis dengan menggunakan kriteria sebagai berikut.
a. $90-100$
= baik sekali
b. $75-85$
= baik
c. $60-74$
= cukup/sedang
d. $40-59$
$=$ kurang
e. $0-39$
$=$ kurang sekali

(Sanafiah dkk, 1982: 209) 


\section{Volume: \\ Nomor: \\ Bulan: \\ Tahun: URL: jurnal.ideaspublishing.co.id}

Perolehan nilai setiap siswa melalui tes hasil belajar secara tertulis diolah dengan rumus sebagai berikut.
a) $\mathrm{DSP}=$ Skor capaian tiap siswa
x $100 \%$

b) $\mathrm{DSK}=$ Skor capaian total seluruh siswa

x $100 \%$

Keterangan:

DSP = Daya Serap Perorangan

DSK = Daya Serap Klasikal

Untuk data hasil belajar siswa secara persentase dianalisis dengan menggunakan permaknaan nilai sebagai berikut.
a. $80-100=$ baik
b. $60-69=$ cukup
c. $30-59=$ kurang
d. $0-29=$ sangat kurang (Sudijono, $1997: 5$ )

\section{Hasil dan Pembahasan}

\section{Hasil}

\section{Hasil Pengamatan Kegiatan Pembelajaran Siklus I}

Kegiatan pembelajaran siklus I dipantau oleh guru mitra melalui lembar observasi.

\section{Hasil Pengamatan Kegiatan Guru}

Kegiatan peneliti dalam proses pembelajaran diamati dengan menggunakan lembar pengamatan kegiatan yang meliputi 25 aspek.

Tabel 1 Hasil Pengamatan Kegiatan Guru pada Siklus I

\begin{tabular}{clcc}
\hline No. & \multicolumn{1}{c}{ Kriteria Aspek } & Jumlah Aspek & Hasil (\%) \\
\hline 1. & Baik sekali & 3 & 12 \\
2. & Baik & 15 & 60 \\
3. & Cukup & 7 & 28 \\
4. & Kurang & - & - \\
\hline \multicolumn{2}{r}{ Jumlah } & 25 & 100 \\
\hline
\end{tabular}

\section{Hasil Pengamatan Kegiatan Siswa}

Kegiatan siswa dalam proses belajar yang dilakukan oleh peneliti diamati oleh guru mitra melalui lembar kegiatan siswa. Lembar kegiatan ini terdiri dari 14 aspek. Hasil pengamatan kegiatan ini disajikan dalam tabel 2. 
URL: jurnal.ideaspublishing.co.id Tahun:

Tabel 2 Hasil Pengamatan Kegiatan Siswa pada Siklus I

\begin{tabular}{clcc}
\hline No. & \multicolumn{1}{c}{ Kriteria Aspek } & Jumlah Aspek & Hasil (\%) \\
\hline 1. & Baik sekali & 2 & 14 \\
2. & Baik & 6 & 43 \\
3. & Cukup & 6 & 43 \\
4. & Kurang & - & - \\
\hline \multicolumn{2}{r}{ Jumlah } & 14 & 100 \\
\hline
\end{tabular}

\section{Hasil Belajar Siswa pada Siklus I}

Hasil belajar siswa pada tahap I merupakan gambaran keberhasilan kegiatan pembelajaran. Tingkat penguasaan siswa pada materi reduksi oksidasi dijaring melalui tes tertulis. Tes pada tahap I terdiri dari 10 butir soal dengan skor tiap butir soal adalah 4 dan 6 , sehingga skor maksimal adalah 42. Adapun rentang nilai yang digunakan yaitu 1-100. Dari hasil analisis tes pada siklus I diperoleh $70 \%$ siswa yang mendapat nilai diatas 75 , dengan rata-rata 81,6 dan 3,0 \% siswa mendapat nilai dibawah 75 dengan rata-rata 73,6. Nilai ratarata kelas 78,16 dan daya serap klasikal 73,34 \%. Analisis tes tahap I secara lengkap disajikan dalam lampiran 6.

\section{Refleksi Tindakan Siklus I}

Berdasarkan refleksi guru mitra dan peneliti terhadap hasil belajar siswa pada siklus I dan observasi kegiatan pembelajaran, maka disimpulkan bahwa tindakan kelas yang dilakukan belum terlaksana sebagaimana diharapkan. Dari hasil pengamatan guru mitra ternyata masih terdapat beberapa aspek yang belum optimal berlangsung dalam proses pembelajaran yaitu:

1. apersepsi dan motivasi;

2. kekomunikatifan pertanyaan;

3. kemampuan memberi penguatan dan peranan guru menyelesaikan masalah.

Berdasarkan temuan-temuan tersebut, maka tindakan yang dilakukan pada siklus I belum mencapai hasil yang diharapkan sehingga masih perlu dilanjutkan ke siklus berikutnya. Tahap II yang akan dilaksanakan merupakan penyempurnaan tindakan yang dilaksanakan pada siklus I. Berdasarkan hasil refleksi pada siklus I, maka pada tindakan tahap II, guru harus melakukan penyempurnaan pada aspek-aspek kegiatan pembelajaran sebagai berikut. 


\section{\begin{tabular}{r|l}
$\begin{array}{r}\text { Volume: } \\
\text { Nomor: } \\
\text { Bulan: } \\
\text { Tahun: }\end{array}$ & P-ISSH: 2656-9451: 2442-367X \\
URL:jurnal.ideaspublishing.co.id
\end{tabular}}

a. Lebih mengoptimalkan pemberian apersepsi dan motivasi di awal kegiatan pembelajaran dengan memberitahukan kepada siswa tentang pentingnya penguasaan materi sebagai prasyarat untuk ke materi selanjutnya, terutama bagi siswa yang bermasalah sehingga siswa tersebut dapat lebih merespon materi yang diberikan dengan baik.

b. Lebih meningkatkan kekomunikatifan pertanyaan melalui penyempurnaan aspek intonasi dan pertanyaan yang diajukan.

c. Guru lebih memfokuskan pertanyaan dengan argumen yang logis dan kuat.

\section{Hasil Pengamatan Kegiatan Pembelajaran Siklus II}

\section{Hasil Pengamatan Kegiatan Guru}

Pembelajaran tahap II yang dilaksanakan oleh peneliti diamati oleh guru mitra, pengamatan meliputi 25 aspek yang diperoleh dan secara ringkas disajikan pada tabel 3.

Tabel 3 Hasil Pengamatan Kegiatan Guru pada Siklus II

\begin{tabular}{clcc}
\hline No. & \multicolumn{1}{c}{ Kriteria Aspek } & Jumlah Aspek & Hasil (\%) \\
\hline 1. & Baik sekali & 12 & 48 \\
2. & Baik & 13 & 52 \\
3. & Cukup & - & - \\
4. & Kurang & - & - \\
\hline \multicolumn{2}{r}{ Jumlah } & 25 & 100 \\
\hline
\end{tabular}

\section{Hasil Pengamatan Kegiatan Siswa}

Pengamatan kegiatan siswa dalam proses pembelajaran dilakukan oleh guru mitra. Dari 14 aspek yang diamati, diperoleh data sebagaimana disajikan dalam lampiran 9 dan secara ringkas disajikan pada tabel 4.

Tabel 4 Hasil Pengamatan Kegiatan Siswa pada Siklus II

\begin{tabular}{clcc}
\hline No. & \multicolumn{1}{c}{ Kriteria Aspek } & Jumlah Aspek & Hasil (\%) \\
\hline 1. & Baik sekali & 8 & 57 \\
2. & Baik & 6 & 43 \\
3. & Cukup & - & - \\
4. & Kurang & - & - \\
\hline \multicolumn{2}{r}{ Jumlah } & 14 & 100 \\
\hline
\end{tabular}




\section{TE-ISSH: 2656-940X Volume: \\ P-ISSH: 2442-367K Nomor: \\ URL: jurnal.ideaspublishing.co.id Tahun:}

\section{Hasil Belajar Siswa Siklus II}

Keberhasilan tindakan pada siklus ini dapat diketahui dengan menilai penguasaan siswa terhadap materi yang dibelajarkan. Siswa diberikan evaluasi dalam bentuk tes. Tes pada siklus II terdiri dari 10 butir soal dengan skor tiap soal adalah 4 dan 5. Dengan demikian, skor maksimal adalah 46. Hasil analisis tes diperoleh 86,7\% siswa yang memperoleh nilai di atas 75 dengan rata-rata 83,0 dan 13,3\% siswa memperoleh nilai di bawah 75 dengan rata-rata 72,5. Nilai rata-rata kelas pada tahap II yakni 84,9 dengan daya serap klasikal 79,45 \%.

\section{Refleksi Hasil Tindakan Siklus II}

Refleksi dilakukan pada akhir siklus dengan tujuan untuk mendapatkan gambaran tentang tindakan yang dilaksanakan dalam meningkatkan hasil belajar siswa. Berdasarkan refleksi tersebut, maka hasil yang diperoleh telah mencapai target yang diharapkan sehingga tidak perlu lagi untuk melanjutkan pada siklus selanjutnya. Walaupun hasil belajar siswa telah mencapai kriteria yang diharapkan, namun guru masih perlu menindaklanjuti beberapa hal yaitu kepada siswa yang belum berhasil atau nilainya kurang dari 75,0 dilakukan remedial, sehingga siswa tersebut mencapai ketuntasan belajar.

\section{Pembahasan}

Pembelajaran konsep atau materi ikatan kimia dengan metode diskusi kelompok, eksperimen, tanya jawab, pembelajaran STEM PBL science diawali dengan pemberian apersepsi dan motivasi yang selanjutnya guru membagi siswa dalam kelompok. Tindakan yang diupayakan terjadi adalah interaksi antara siswa dalam kelompok. Tipe pembelajaran ini memberikan kesempatan yang merata kepada masing-masing anggota kelompok untuk memberikan pendapat secara bergiliran yang telah diatur sebelumnya. Juga dapat memperlihatkan hasil rancangannya, yaitu bentuk molekul dari $\mathrm{BeCl}_{2}, \mathrm{BeCl}_{3}, \mathrm{CH}_{4}, \mathrm{PCl}_{5}, \mathrm{SF}_{6}$. Selain itu pula, para siswa dibiasakan mendengarkan pendapat anggota lain dalam kelompoknya dan harus menerima pendapat orang lain sehingga siswa yang pandai dapat membantu teman lain untuk menyumbangkan pikiran dan pengetahuan yang dimilikinya.

Strategi pendekatan pembelajaran STEM (Science, Technology, Engieering, dan Mathematics) dapat meningkatkan keaktifan belajar siswa dan menciptakan ketergantungan positif untuk mencapai tujuan belajar. Saling ketergantungan antara siswa yang disusun secara 


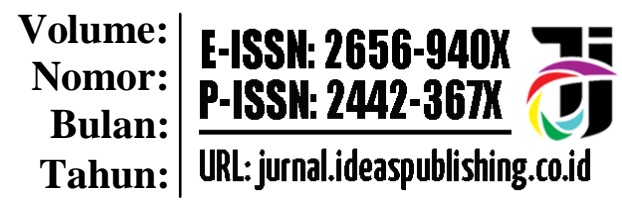

cermat dapat meningkatkan keterampilan berpikir siswa, sehingga tujuan pembelajaran per individu dapat tercapai.

Hasil penelitian menunjukkan adanya peningkatan hasil belajar siswa dari tahap I ke tahap II yaitu dari $70 \%$ ke 86,7 \%. Hal ini terjadi karena berbagai alternatif tindakan digunakan dalam proses pembelajaran. Walaupun pada penelitian ini hasil belajar siswa pada konsep reaksi oksidasi-reduksi telah dapat ditingkatkan, tetapi pengembangan dan pembenahan dalam kegiatan pembelajaran lebih lanjut terus dilakukan untuk mendapatkan hasil yang lebih baik.

Dengan sifat heterogen yang ada dalam kelompok dan kerja sama yang tercipta, siswa mampu bekerja sama dan saling membantu siswa lain yang belum tuntas materinya. Evaluasi yang dilakukan pada tahap I menunjukkan bahwa 21 orang (70\%) siswa yang mendapat nilai di atas 75 dengan nilai rata-rata 78,16. Jumlah ini masih relatif rendah yang disebabkan oleh berbagai faktor, antara lain belum maksimalnya proses pembelajaran yang diterapkan oleh guru berupa kurangnya apersepsi dan motivasi yang diberikan guru kepada siswa dalam merespon pelajaran yang diberikan. Selain itu, optimalnya kekomunikatifan pertanyaan dan penguatan yang diberikan guru.

Berbagai kekurangan pada siklus I ini selanjutnya disempurnakan pada siklus berikutnya (Siklus II). Pada Siklus II hasil evaluasi yang dilakukan pada akhir pembelajaran menunjukkan bahwa 26 orang $(86,7 \%)$ memperoleh hasil belajar di atas 75 dengan nilai ratarata $84,9 \%$. Secara singkat perbandingan antara hasil belajar siswa pada siklus I dan siklus II disajikan dalam tabel 5 .

Tabel 5 Perbandingan Hasil Belajar Siswa pada Siklus I dan Siklus II

\begin{tabular}{cccccc}
\hline Siklus & $\begin{array}{c}\text { \% Siswa yang } \\
\text { Mendapat Nilai } \geq 75\end{array}$ & \multicolumn{4}{c}{ Jumlah Siswa dalam Kriteria } \\
\cline { 3 - 6 } & $\begin{array}{c}\text { Baik } \\
\text { Sekali }\end{array}$ & Baik & Cukup & Kurang \\
\hline I & $70 \%$ & - & 18 & 12 & - \\
\hline II & $86,7 \%$ & 6 & 18 & 6 & - \\
\hline
\end{tabular}

Pada tabel 5 menunjukkan terdapat kenaikan 16,7\% dari siklus I ke siklus II. Dengan demikian, pembelajaran menggunakan pendekatan berbasis STEM PBL Sciensi dapat meningkatkan hasil belajar siswa pada konsep Ikatan Kimia.

\section{Simpulan}




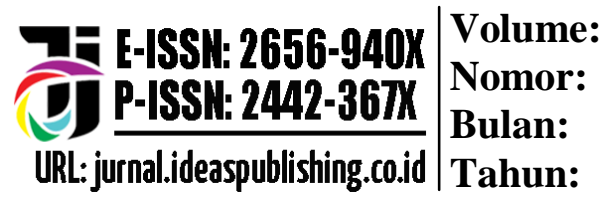

Berdasarkan hasil pembahasan serta mengacu pada permasalahan dan tujuan penelitian ini, maka metode pembelajaran menggunakan pendekatan berbasis STEM PBL science dalam kegiatan pembelajaran konsep ikatan kimia dapat meningkatkan hasil belajar siswa kelas XIPA 3 SMA Negeri 4 Kota Gorontalo. Terdapat peningkatan hasil belajar siswa dari siklus I ke siklus II yakni dari $70 \%$ ke 86,7 \% atau meningkat sebesar $16,7 \%$. Metode pembelajaran menggunakan pendekatan berbasis STEM PBL Science perlu diupayakan dalam meningkatkan hasil belajar siswa pada konsep lain dalam pembelajaran kimia bahkan dikombinasikan dengan metode pembelajaran lain sehingga tercipta suasana pembelajaran yang lebih menarik minat belajar siswa.

\section{Daftar Pustaka}

Amelia, Ana. (2018). Penerapan Model Pembelajaran Problem Based Learning Berbasis STEM (Science, Technology, Engineering And Mathematics) untuk Meningkatkan Kemampuan Pemecahan Masalah Matematika Materi Program Linear Siswa Kelas XI IPA MA Nasruddin Dampit Tahun Akademik 2018/2019.

Hidayat, Jamaludin. (2007). Pelajaran Kimia SMA/MA Kelas X. Jakarta: Erlangga.

Kurniawan, Haviz. (2014). Implementasi Pembelajaran IPA Berbasis STEM untuk Meningkatkan Kemampuan Komunikasi Siswa.

Purba, Michael. 2006. Kimia untuk SMA Kelas X. Jakarta: Erlangga.

Pomalato, Sarson, W. Dj dan Hulukati Evi P. (1999). Penelitian Tindakan Kelas. Gorontalo: STIKIP Gorontalo.

Parning, Horale. (2004). Kimia 1B SMA. Klaten: Yudhistira.

R.W, Dahar. (1989). Teori-Teori Belajar. Jakarta: Depdikbud.

Sari, Marthalenta. (2017). Penerapan Pembelajaran Fisika Berbasis Stem (Science, Technology, Engineering, And Math) dengan Menggunakan Model Siklus Belajar 5E untuk Meningkatkan Penguasaan Konsep Siswa.

Sa'adhah, Evawati. (2019). Penerapan Model Pembelajaran STEM (Science, Technology, Engineering And Mathematics) sebagai Upaya Meningkatkan Keaktifan dan Hasil Belajar Siswa pada Mata Pelajaran Dasar Listrik dan Elektronika di Smk N 1 Nanggulan.

Susilowati, Endang. (2013). Kimia 1 untuk Kelas X SMA/MA. Wangsa Jatra Sari Lestari.

Suharyanto, M.Pd. (2004). Model-Model Pembelajaran. Workshop Master Teacher untuk Madrasah Aliyah Model Seluruh Indonesia. Makalah tidak diterbitkan, disampaikan dalam pelatihan guru bina untuk Madrasah Aliyah Model Yogyakarta. Universitas Negeri Yogyakarta.

Umiyati, Nurhalima. (2016). Kimia Kelas X Peminatan Matematika dan Ilmu-ilmu Alam. Media Utama Surakarta. 